\title{
Analisis Status Badan Hukum Dana Pensiun
}

\author{
Muhhammad Habibi Miftakhul Marwa
}

\begin{abstract}
Law Number 11 of 1992 concerning Pension Funds states that pension funds are legal entities that manage and run pension programs that promise retirement benefits when they have retired or are retired to their participants. As a legal entity, the pension fund is located as a legal subject just like humans, who have rights and obligations so they can take legal actions to other parties. Pension funds have legal entity status and may carry out activities from the date of approval by the Financial Services Authority. Judging from the theory and requirements of legal entities, pension fund legal entities have fulfilled both material and formal requirements in the formation of pension funds, such as having assets separate from its founder, having specific objectives for administering pension benefits, having their interests, has an organized organization in the division of tasks and functions between the founder, the board of trustees, and the board, and obtains recognition and endorsement from state authorities. Pension funds as independent legal entities do not use legal entities such as Limited Liability Companies, Cooperatives, or Foundations, because there are concepts in the legal entity that are not by the concept of pension funds.
\end{abstract}

Keywords: Legal Subject; Legal Entity; Pension Fund

\begin{abstract}
Abstrak
Undang-Undang Nomor 11 Tahun 1992 tentang Dana Pensiun menyebutkan bahwa dana pensiun adalah badan hukum yang mengelola dan menjalankan program pensiun yang menjanjikan manfaat pensiun pada saat telah pensiun atau pensiun kepada pesertanya. Sebagai badan hukum, dana pensiun terletak sebagai subjek hukum layaknya manusia, yang memiliki hak dan kewajiban sehingga dapat melakukan perbuatan hukum kepada pihak lain. Dana pensiun berbadan hukum dan dapat melaksanakan kegiatan sejak tanggal persetujuan Otoritas Jasa Keuangan. Dilihat dari teori dan persyaratan badan hukum, badan hukum dana pensiun telah memenuhi persyaratan baik materiil maupun formil dalam pembentukan dana pensiun, seperti memiliki kekayaan yang terpisah dari pendirinya, mempunyai tujuan khusus dalam menyelenggarakan manfaat pensiun, memiliki kepentingan, menyelenggarakan organisasi dalam pembagian tugas dan fungsi antara pendiri, dewan pengawas, dan pengurus, serta memperoleh pengakuan dan pengesahan dari otoritas negara. Dana pensiun sebagai badan hukum mandiri tidak menggunakan badan hukum seperti Perseroan Terbatas, Koperasi, atau Yayasan, karena terdapat konsep dalam badan hukum yang tidak sesuai dengan konsep dana pensiun.
\end{abstract}

\section{Jurnal}

Kata Kunci: Subjek Hukum; Badan Hukum; Dana Pensiun

\section{YUSTIIKA 1. Pendahuluan}

Program dana pensiun sekarang ini tidak hanya bisa dinikmati oleh Aparatur Sipil Negara (ASN), TNI, dan Polri. Sejak disahkan Undang-Undang No. 11 Tahun 1992 tentang Dana Pensiun (Undang-Undang Dana Pensiun), maka setiap karyawan swasta atau karyawan mandiri yang menghendaki kesejahteraan setelah mencapai usia pensiun dapat bergabung 
dalam program pensiun. Program ini dibentuk salah satu tujuannya untuk merencanakan masa depan dan menjamin kesinambungan penghasilan karyawan ketika sudah purna tugas sesuai dengan perjanjian kerja yang disepakati. Idealnya setiap karyawan harus mampu merencanakan hidup di masa tuanya, karena secara fisik sudah mengalami penurunan produktifitas dalam bekerja.

Keberadaan program dana pensiun bagi karyawan dapat memberikan rasa aman dan ketentraman, karena adanya penghasilan tambahan yang dipersiapkan jauh sebelumnya dan dapat diambil manfaatnya saat purna bakti. Program ini juga merupakan tanggung jawab moral pemberi kerja kepada karyawannya untuk motivasi dan meningkatkan kinerja karyawan supaya lebih giat dan loyal dalam bekerja, sehingga perusahaan semakin produktif dalam menjalankan usahanya. Bagi pemerintah program pensiun mampu menciptakan stabilitas negara, di mana tingkat kerawanan sosial dapat diminimalisir dengan adanya program tersebut. Adanya program pensiun juga mampu membiayai pembangunan nasional guna mewujudkan kesejahteraan masyarakat yang bersumber dari hasil iuran peserta pensiun dan hasil investasi yang dilakukan di berbagai sektor (Wahab, 2001).

Hakikatnya program dana pensiun merupakan tabungan jangka panjang peserta dana pensiun, di mana peserta baru bisa menikmati hasilnya setelah pensiun. Hasil yang diperolehnya didasarkan pada akumulasi dana selama masa kepesertaan program pensiun. Apabila peserta meninggal atau cacat sebelum masa pensiun, maka peserta berhak mendapatkan manfaat pensiun dari pemberi kerja. Sebagai fungsi pensiun maka hasil pengelolaan program dana pensiun akan dibayarkan oleh pemberi kerja kepada sejak usia pensiun sampai meninggal dunianya peserta pensiun.

Dengan demikian, dana pensiun dapat dimaknai sebagai dana yang dihimpun secara khusus untuk memberikan manfaat kepada peserta pensiun ketika mecapai usia pensiun (retirement), mengalami cacat (disability), atau meninggal dunia (death). Dana yang dihimpun tersebut kemudian dikelola oleh suatu lembaga yang disebut trust, sedangkan pengelola trust disebut trustee. Melihat fungsi program pensiun yang demikian positif, maka tidak mengherankan manakala banyak pemberi kerja atau perusahaan membentuk program dana pensiun bagi karyawannya.

Tebel 1.

Jumlah Pelaku Dana Pensiun Per 2019

\begin{tabular}{|c|c|c|c|c|c|c|c|c|c|}
\hline Jenis Program & $\begin{array}{l}\text { Jan } \\
-19 \\
\end{array}$ & $\begin{array}{l}\text { Feb } \\
-19 \\
\end{array}$ & $\begin{array}{c}\text { Mar } \\
-19\end{array}$ & $\begin{array}{l}\text { Apr } \\
-19 \\
\end{array}$ & $\begin{array}{c}\text { Mei } \\
-19 \\
\end{array}$ & $\begin{array}{l}\text { Jun } \\
-19 \\
\end{array}$ & $\begin{array}{c}\text { Jul } \\
-19 \\
\end{array}$ & $\begin{array}{c}\text { Aug } \\
-19 \\
\end{array}$ & $\begin{array}{l}\text { Sep } \\
-19 \\
\end{array}$ \\
\hline DPPK-PPMP & 162 & 162 & 162 & 162 & 162 & 162 & 162 & 159 & 159 \\
\hline DPPK-PPIP & 41 & 41 & 41 & 41 & 41 & 41 & 41 & 42 & 41 \\
\hline DPLK & 24 & 24 & 24 & 24 & 23 & 24 & 24 & 25 & 25 \\
\hline Dana Pensiun & 227 & 227 & 227 & 227 & 226 & 227 & 227 & 226 & 225 \\
\hline
\end{tabular}

Sumber: www.ojk.go.id

Data di atas menunjukkan bahwa Pelaku Dana Pensiun di Indonesia mengalami perubahan jumlah, baik Dana Pensiun Lembaga Keuangan (DPLK) yang dibentuk oleh Bank atau Perusahaan Asuransi Jiwa, maupun Dana Pensiun Pemberi Kerja (DPPK) dengan Program Pensiun Manfaat Pasti (PPMP) atau Program Pensiun Iuran Pasti (PPIP). Hal ini tidak lepas dari kebijakan Otoritas Jasa Keuangan (OJK) selaku pemegang otoritas di bidang dana pensiun. Menurut Peraturan Otoritas Jasa Keuangan (POJK) Nomor 13/POJK.05/2016 tentang Tata Cara 
Jurnal Yustika

Vol. 23 No. 01, Jul 2020

Halaman I 3

Analisis Status

Badan Hukum

Dana Pensiun

Muhhammad Habibi Miftakhul Marwa
Permohonan Pengesahan Pembentukan Dana Pensiun Pemberi Kerja Dan Pengesahan Atas Perubahan Peraturan Dana Pensiun Dari Dana Pensiun Pemberi Kerja, bahwa setiap pembentukan (bertambah) dana pensiun wajib mendapat pengesahan OJK, sedangkan pembubaran (berkurang) dana pensiun juga ditetapkan oleh OJK.

Dana pensiun berstatus sebagai badan hukum ditegaskan dalam Pasal 1 angka 1 Undang-Undang Dana Pensiun, bahwa dana pensiun adalah badan hukum yang menjalankan program yang menjanjikan manfaat pensiun bagi pesertanya. Bentuk hukum dana pensiun sebagai badan hukum yang menyelenggarakan program pensiun dikenal sejak disahnnya Undang-Undang Dana Pensiun. Ini merupakan bentuk pengakuan negara terhadap eksistensi dana pensiun di Indonesia.

Badan hukum (legal person, legal entity, rechtspersoon, persona moralis ) adalah suatu badan yang mempunyai hak dan kewajiban sehingga mampu melakukan perbuatan hukum (rechtsbetrekking/rechtsverhouding) seperti manusia (natuurlijkpersoon), memiliki harta kekayaan sendiri, dan dapat digugat dan menggugat di depan pengadilan (Khairandy, 2008). Badan hukum sebagai subjek hukum yang tidak berjiwa merupakan lawan dari pendukung hak dan kewajiban yang berjiwa (manusia).

Diakuinya dana pensiun sebagai badan hukum, maka istilah badan hukum privat di Indonesia mengalami penambahan, selain Perseroan Terbatas (PT), Yayasan, dan Koperasi. Di Indonesia syarat-syarat dan tata cara pendirian badan hukum privat tergantung dengan jenis badan hukum yang bersangkutan. Misalnya, pendirian Perseroan Terbatas mengacu pada UU No. 40 Tahun 2007 tentang Perseroan Terbatas, Koperasi didirikan harus sesuai ketentuan UU No. 25 Tahun 1992 tentang Perkoperasian, dan pendirian Yayasan diatur dalam UU No. 16 Tahun 2001 tentang Yayasan kemudian diubah dan ditambah dengan UU No. 28 tahun 2004 tentang Perubahan dan Penambahan UU No. 16 Tahun 2001 tentang Yayasan.

Sebelum Undang-Undang Dana Pensiun disahkan, penyelenggaraan program pensiun mengacu pada Arbeidersfondsen Ordonnantie Tahun 1926 Nomor 377, sebagai pelaksana Pasal 1601 (s) buku III HUH Perdata, dikenal beberapa istilah program pensiun, yakni (Wahab, 2001):

1. Program pensiun yang dikelola perusahaan kemudian dibayarkan dari cadangan perusahaan (book reserves) atau biaya perusahaan (pay as you go);

2. Program pensiun yang dikelola yayasan dana pensiun yang telah memperoleh pengesahan Kementrian Keuangan;

3. Program pensiun Pegawai Negeri Sipil (PNS) dan pejabat negara lainnya yang dikelola oleh PT. Taspen;

4. Program pensiun bagi anggota TNI dan Polri yang dikelola oleh PT. Asabri.

\section{Rumusan Masalah}

Melihat praktik penyelenggaraan program dana pensiun sebagaimana penjelasan di atas, maka timbul pertanyaan, (1) Bagaimana kedudukan badan hukum sebagai subjek hukum? (2) Mengapa program dana pensiun tidak menggunakan bentuk badan hukum yang sudah ada?

\section{Pembahasan}

\subsection{Badan Hukum Sebagai Subjek Hukum}

Subjek hukum dalam literatur ilmu hukum didefinisikan sebagai sesuatu yang menurut hukum dapat mempunyai hak dan kewajiban serta memiliki kewenangan dan kehendak untuk bertindak hukum. Konsep subjek hukum dapat dipahami sebagai orang (badan) yang menjadi 
subjek dari kewajiban dan hak hukum. Subjek hukum bukanlah suatu entitas yang terpisah di samping hak dan kewajiban, melainkan hanyalah kesatuan yang dipersonifikasikan dari seperangkat norma hukum sehingga memiliki wewenang untuk mempunyai hak dan wewenang untuk melakukan perbuatan hukum (Murtir, 2012).

Subjek hukum dalam khasanah hukum perdata selain manusia sebagai naturlijkperson, ada juga badan hukum sebagai rechtperson yang berkedudukan sebagai penyandang hak dan kewajiban. Adanya badan hukum di samping manusia adalah suatu realita yang timbul sebagai suatu kebutuhan hukum dalam kehidupan masyarakat. Istilah badan hukum dalam dalam kepustakaan hukum Belanda disebut rechtsperson, atau dalam tradisi common law disebut dengan juristic person, artificial person, atau legal entity. Rechtperson diartikan sebagai badan hukum yang merupakan person ficti atau diciptakan hukum sebagai persona (Prananingrum, 2014), sedangkan legal entity merupakan badan atau organisasi yang diperlakukan sebagai subjek hukum yang memegang hak dan kewajiban (Widjaja, 2008). Rechtperson ini bagian dari kreasi yang diciptakan oleh hukum dengan menghadirkan teori organ supaya badan hukum dapat bertindak seperti manusia dengan menggunakan perantara organisasi badan hukum atau melalui pengurusnya.

Menurut (Black, 1990), artificial person didefinisikan sebagai "persons created and devised by human laws for the purposes of society and government, as distinguished from natural person", sementara legal entity adalah "an entity, other than natural person, who has sufficient existence in legal contemplation that it can function legally, be sued or sue and make decisions through agents as in the case of corporation." Sedangkan menurut Salmond (dalam Marzuki, 2015), " a legal person is any subject matter other than human being to which the law attributes personality." Definisi tersebut menunjukkan bahwa badan hukum merupakan subjek hukum (selain manusia) yang diakui oleh negara melalui instrumen hukum positif, memiliki kewenangan dan kedudukan melakukan kegiatan hukum dengan pihak lain.

Menurut Subekti, badan hukum adalah suatu badan atau perkumpulan yang dapat memiliki hak melakukan perbuatan hukum seperti manusia, serta memiliki kekayaan sendiri, dapat digugat atau menggugat di depan hakim (Subekti, 1980). Oleh karena itu, badan hukum sebagai subjek hukum mencakup beberapa hal, seperti perkumpulan orang atau organisasi, dapat melakukan perbuatan hukum (recthhandeling), memiliki kekayaan tersendiri, memiliki pengurus memiliki hak dan kewajiban, serta dapat digugat atau menggugat.

Definisi di atas, menginformasikan bahwa ukuran untuk menentukan badan hukum atau bukan badan hukum adalah mempunyai perkumpulan, adanya kekayaan yang terpisah antara kekayaan pribadi dengan kekayaan pekumpulan, memiliki kepentingan bersama (tujuan) yang harus dicapai dalam perkumpulan orang-orang tersebut. Selain itu, badan hukum atau rechtperson dicirikan sebagai orang yang diciptakan oleh hukum (negara) yang mempunyai hak dan kewajiban sehingga mampu melakukan perbuatan hukum, dan mempunyai hak untuk menggugat dan digugat di pengadilan.

Menurut Munir Fuady (dalam Imaniyati \& Putra, 2017), disebut subjek hukum jika dalam badan hukum memenuhi unsur-unsur seperti memiliki harta kekayaan yang terpisah, memiliki tujuan tertentu, memiliki kepentingan tertentu, dan memiliki organisasi yang teratur. Dari unsur-unsur tersebut terdapat 2 (dua) unsur penting badan hukum, yaitu terdapat pemisahan hak dan kewajiban badan hukum dengan para anggotanya, dan eksistensi badan hukum tidak hilang meskipun organisasinya berganti-ganti. Dengan demikian, badan hukum sebagai subjek hukum maka padanya melekat hak dan kewajiban yang berdiri sendiri dan statusnya 
Jurnal Yustika

Vol. 23 No. 01, Jul 2020

Halaman I 5

Analisis Status

Badan Hukum Dana Pensiun

Muhhammad Habibi Miftakhul Marwa dipersamakan dengan manusia. Namun, badan hukum tidak serta merta memperoleh status sebagai subjek hukum sebelum memalui proses pendaftaran hingga pengesahan.

Badan hukum ini merupakan suatu entitas yang unik, karena di satu sisi badan hukum sebagai orang atau legal person, namun di sisi lain badan hukum merupakan benda sebagai objek hukum. Sehingga, badan hukum yang diibaratkan sebagai orang dapat memiliki benda, tetapi badan hukum sebagai benda dimiliki oleh orang. Bahkan sebagai subjek hukum, badan hukum dapat memiliki badan hukum lain dalam kedudukan badan hukum lain tersebut sebagai benda (Fuady, 2013). Filosofi pendirian badan hukum menurut Nindyo Pramono (dalam Khairandy, 2008) adalah apabila pendirinya meninggal dunia maka harta kekayaan badan hukum yang terpisah dengan pendiri masih dapat bermanfaat bagi orang lain atau generasi berikutnya. Maka, untuk mewujudkan yang demikian itu hukum menciptakan suatu kreasi yang oleh hukum diakui sebagai subjek hukum yang mandiri seperti manusia (natuurlijk person atau natural person). Kreasi tersebut dalam ilmu hukum dikenal dengan badan hukum. Supaya badan badan hukum dapat bertindak hukum seperti manusia maka diperlukan organisasi badan hukum.

Badan hukum merupakan rekayasa manusia untuk membentuk suatu badan yang memiliki status dan kedudukan hukum mandiri yang dipersamakan seperti manusia di hadapan hukum. Kedudukannya tidak sepenuhnya sama seperti manusia dalam menyandang hak dan kewajiban. Dipersamakan dengan manusia sebagai subjek hukum hanya dalam hal hukum harta kekayaan (hukum kebendaan dan hukum perikatan). Hukum orang, hukum keluarga, dan hukum waris tidak berlaku dalam badan hukum. Badan hukum dapat menggugat dan digugat di pengadilan untuk memenuhi perikatannya, sedangkan kebendaan yang merupakan milik badan hukum menjadi tanggungan bagi pemenuhan kewajiban badan hukum tersebut. Selain itu, perbedaan badan hukum dengan manusia sebagai pembawa hak adalah badan hukum tidak dapat melangsungkan perkawinan, tidak dapat dihukum penjara, tetapi badan hukum dimungkinkan dikenakan pidana (tindak pidana korporasi) bahkan badan hukum dapat dibubarkan (Irwansyah, 2020).

Konsep badan hukum sebagai rekayasa manusia sejalan dengan teori fiksi yang dipelopori oleh Friedrich Carl von Savigny, sarjana Jerman sekitar tahun 1779-1861. Teori ini menjelaskan bahwa badan hukum sebenarnya rekayasa manusia, fiksi manusia, abstraks, dan bukan sesuatu yang konkrit. Keberadaan badan hukum dasarnya adalah hukum positif pada suatu negara, sehingga negara mengakui dan menjamin personalitas hukum badan hukum tersebut (Khairandy, 2008). Sebagai bayangan yang sebenarnya tidak ada, badan hukum sengaja dihidupkan melalui orang (pengurus) supaya dapat menerangkan kepada orang lain dari yang abstraks menjadi konkrit. Hanya manusia melalui organisasi badan hukum yang dapat menjelaskan dan mewakili badan hukum dalam aktivitas hukumnya.

Menurut teori organ (organic theory) sebagaimana yang diajarkan sarjana Jerman bernama Otto von Gierke (1841-1921), menyatakan bahwa badan hukum merupakan suatu yang nyata (realita) bukan fiksi. Oleh karena itu badan hukum dapat memenuhi kehendaknya sama seperti manusia. Menurut teori ini badan hukum sebenarnya merupakan konstruksi yuridis yang berwujud seperti manusia, sehingga dapat mempunyai kehendak sendiri melalui alat kelengkapan (organ) yang ada padanya (pengurus) sehingga bukan sesuatu yang fiksi (Saebani et al., 2016). Badan hukum memiliki pemikiran yang benar-benar riil, kehendak yang benar-benar nyata, dan kewenangan yang benar-benar nyata. Bahkan kelompok manusia sebenarnya benar-benar memiliki suatu kesadaran kolektif sehingga memiliki kesadaran diri 
sebagai kelompok yang benar-benar terpisah dari kesadaran individu (Fuady, 2013). Segala keputusan yang dibuat oleh pengurus adalah kehendak badan hukum yang bersifat kolektif.

Badan hukum itu menjadi subjek hukum oleh karena organ perlengkapannya sama seperti alat perlengkapan yang dimiliki anggota badan manusia. Badan hukum dalam menjalankan fungsinya juga memiliki organ seperti manusia misal organ jantung, paru-paru, ginjal, dan sebagainya, yang dalam badan hukum terdapat organ yang diperankan oleh pengurus (Irwansyah, 2020). Dengan demikian, dapat dipahami jika badan hukum adalah sesuatu yang nyata.

Sebagai subjek hukum maka badan hukum harus memenuhi syarat materiil dan formil. Adapun syarat materiil (substantif) bagi suatu badan hukum adalah adanya pemisahan harta kekayaan antara kekayaan pendiri dan kekayaan badan hukum, mempunyai tujuan tertentu atas didirikannya badan hukum tersebut, mempunyai kepentingan tersendiri yang dilindungi hukum, dan adanya organisasi yang teratur (Asyhadie, 2018). Sedangkan syarat formil badan hukum, yaitu proses pembentukan badan hukum harus memenuhi formalitas sebagaimana yang ditetapkan dalam peraturan perundang-undangan yang mengaturnya, sehingga keberadaan badan hukum tersebut sah dan diakui oleh negara sebagai subjek hukum yang independen atau mandiri. Inilah yang membedakan antara manusia dengan badan hukum sebagai subjek hukum. Melekatnya hak dan dan kewajiban pada manusia dimulai sejak dilahirkan sampai meninggal dunia, bahkan dalam hal-hal tertentu (warisan) dapat dihitung berlaku surut sejak masih dalam kandungan. Sedangkan badan hukum menyandang hak dan kewajiban setelah mendapatkan pengesahan dari negara.

Penjelasan di atas memperkuat keyakinan dan kedudukan badan hukum merupakan subjek hukum, karena beberapa alasan, yaitu sebagai lembaga mandiri dari pendiri dan anggota badan maka pada badan hukum melekat hak dan kewajiban, dan mampu bertindak hukum. Konsekuensinya, badan hukum dapat melakukan kegiatan bisnis atas nama dirinya sendiri, juga memiliki kewajiban-kewajiban hukum seperti bayar pajak dan mengajukan izin bisnis, serta dalam menjalankan aktivitasnya tidak tergantung pada salah satu organ perkumpulan tersebut namun ditentukan oleh hukum yang mengaturnya.

\subsection{Dana Pensiun Sebagai Badan Hukum}

Badan hukum dana pensiun yang menjadi salah satu badan hukum yang ada di Indonesia kurang dikenal di masyarakat mungkin karena jarang dikenalkan jika dana pensiun merupakan salah satu badan hukum, sama halnya dengan perseroan terbatas, yayasan, dan koperasi. Badan hukum di setiap negara diatur sesuai dengan sistem hukum yang dianutnya. Dana pensiun sebagai badan hukum di Indonesia ditetapkan berdasarkan hukum positif (hukum yang berlaku pada negara tertentu), yaitu Undang-Undang Dana Pensiun. Untuk menentukan suatu badan itu berstatus badan hukum atau bukan badan hukum tergantung dari hukum positif yang berlaku di masing-masing negara. Artinya, setiap negara memiliki kebijakan berbeda mengenai status badan hukum. Misalnya, hukum positif di Perancis mengakui firma sebagai badan hukum, sedangkan di Indonesia firma bukan badan hukum.

Di Indonesia dana pensiun sebagai badan hukum secara tegas dinyatakan dalam Pasal 1 angka 1 Undang-Undang Dana Pensiun, bahwa dana pensiun adalah badan hukum yang mengelola dan menjalankan program yang menjanjikan manfaat pensiun. Kemudian Pasal 3 Undang-Undang Dana Pensiun menjelaskan, bahwa dana pensiun memiliki status sebagai badan hukum dengan syarat dan tata cara yang diatur dalam Undang-Undang Dana Pensiun. 
Jurnal Yustika

Vol. 23 No. 01, Jul 2020

Halaman 17

Analisis Status

Badan Hukum

Dana Pensiun

Muhhammad Habibi Miftakhul Marwa
Pembentukan dana pensiun sebagai badan hukum berbeda dengan pendirian badan usaha pada umumnya, seperti pendirian yayasan atau perseroan terbatas. Menurut Pasal 5 ayat 1 Undang-Undang Dana Pensiun, pembentukan dana pensiun didasarkan pada dokumen berikut ini :

a) Pernyataan tertulis pendiri dana pensiun yang menyatakan keputusannya mendirikan dana pensiun dan memberlakukan Peraturan Dana Pensiun;

b) Peraturan Dana Pensiun yang ditetapkan oleh pendiri;

c) Penunjukkan pengurus, dewan pengawas, dan penerima titipan.

Dalam hal pendiri dana pensiun hendak mengajukan permohonan pembentukan dana pensiun kepada Menteri, maka harus dilakukan secara tertulis menggunakan formulir dengan melampirkan dokumen-dokumen yang telah ditetapkan Pasal 6 Undang-Undang Dana Pensiun seperti melampirkan Peraturan Dana Pensiun, penyataan tertulis pendiri dalam bentuk Surat Keputusan pendirian dana pensiun, penunjukan pengurus, dewan pengawas, dan penerima titipan melalui Surat Keputusan Pendiri, arahan investasi, laporan aktuaris, dan surat perjanjian penerima titipan dengan pengurus dana pensiun.

Badan hukum dana pensiun dapat bertindak sebagai subjek hukum jika sudah didaftarkan dan disahkan oleh otoritas negara. Badan hukum dana pensiun diperoleh setelah mendapatkan pengesahan dari Menteri. Ini ditegaskan dalam Pasal 7 Undang-Undang Dana Pensiun, bahwa dana pensiun memiliki status sebagai badan hukum dan dapat memulai kegiatannya sebagai dana pensiun sejak tanggal pengesahan Menteri. Selama ini badan hukum yang didirikan oleh privat seperti perkumpulan/perhimpunan, perseroan terbatas, firma, koperasi, yayasan, dan lain-lainnya dimintakan pengesahan kepada Menteri Hukum dan HAM, sedangkan khusus untuk badan hukum dana pensiun pengesahannya dilakukan oleh Menteri Keuangan (Sari \& Simangunsong, 2007). Sehingga pembentukan dana pensiun yang seperti ini sangat berbeda dengan pembentukan badan hukum lain di Indonesia yang harus disahkan oleh Menteri Hukum dan HAM. Sejak disahkan Undang-Undang Nomor 21 tahun 2011 tentang Otoritas Jasa Keuangan (OJK), maka per 31 Desember 2012, semua fungsi, tugas, dan wewenang pengaturan dan pengawasan kegiatan jasa keuangan asuransi, dana pensiun, lembaga pembiayaan, dan sektor pasar modal beralih dari Menteri Keuangan dan Badan Pengawas Pasar Modal dan Lembaga Keuangan (Bapepam-LK) ke OJK.

Status badan hukum dana pensiun diperoleh setelah OJK mengesahkan peraturan dana pensiun. Pembentukan dana pensiun tidak memerlukan akta notaris serta pengesahan Menteri Hukum dan HAM, tetapi keduanya harus dimuat dalam Berita Negara Republik Indonesia dan Tambahan Lembaran Berita Negara sebagai bentuk publikasi dan dicatat dalam buku daftar umum. Pembentukannya berdasarkan pernyataan sepihak dari pemberi kerja atau lembaga keuagan dengan mendirikan dana pensiun demi kepentingan peserta. Dana pensiun didirikan dengan peraturan dana pensiun yang sekaligus dijadikan anggaran dasar dan memuat ketentuan penyelenggaraan program pensiun. Peraturan tersebut tidak dibuat dihadapan notaris, namun dibuat oleh pemberi kerja/lembaga keuangan yang menyelenggaran program pensiun.

Pengesahan oleh OJK terhadap badan hukum dana pensiun seperti yang dinyatakan dalam POJK Nomor 13/POJK.05/2016 tentang Tata Cara Permohonan Pengesahan Pembentukan Dana Pensiun Pemberi Kerja dan Pengesahan atas Perubahan Peraturan Dana Pensiun dari Dana Pensiun Pemberi Kerja, yang mencabut Permenkeu No. 227/KMK.017/1993 tentang Tata Cara Permohonan Pengesahan Pembentukan Dana Pensiun Pemberi Kerja, 
Penyesuaian Yayasan Dana Pensiun dan Pengesahan atas Perubahan Peraturan Dana Pensiun dari Dana Pensiun Pemberi Kerja sebagaimana telah diubah dengan Permenkeu No. 344/KMK.017/1998 tentang Perubahan Keputusan Menteri Keuangan Republik Indonesia Nomor 227/KMK.017/1993 tentang Tata Cara Permohonan Pengesahan Pembentukan Dana Pensiun Pemberi Kerja, Penyesuaian Yayasan Dana Pensiun dan Pengesahan atas Perubahan Peraturan Dana Pensiun dari Dana Pensiun Pemberi Kerja. Serta POJK No.14/POJK.05/2016 tentang Pengesahan Pendirian Dana Pensiun Lembaga Keuangan dan Perubahan Peraturan Dana Pensiun dari Dana Pensiun Lembaga Keuangan mencabut Permenkeu No.21/PMK.010/2011 tentang Pengesahan Pendirian Dana Pensiun Lembaga Keuangan dan Perubahan Peratiran Dana Pensiuan dari Dana Pensiun Lembaga Keuangan.

Jika dilihat dari segi objek yang oleh hukum diberikan status pemangku hak dan kewajiban, maka badan hukum dana pensiun masuk kategori badan hukum sebagai perkumpulan harta (Fuady, 2013). Yaitu, bahwa ada sekumpulan harta benda termasuk uang yang dipisahkan dari pemiliknya di mana harta benda tersebut digunakan untuk kepentingan tertentu saja. Dari sini juga ada kepentingan untuk memperlakukan harta benda tersebut sebagai badan hukum. Dalam konteks dana pensiun dana tersebut difungsikan untuk membayar menfaat pensiun jika telah jatuh tempo.

Badan hukum yang merupakan suatu lembaga hasil kreasi hukum tidak dapat melakukan aktivitas sebagaimana manusia yang dapat berkehendak sendiri kecuali dibantu oleh suatu organ badan hukum. Sebagai badan hukum yang berkedudukan sebagai subjek hukum dana pensiun memiliki hak dan kewajiban, serta dapat melakukan tindak hukum dengan pihak lainnya, sehingga pelaksanaan pengelolaan dana pensiun dijalankan oleh alat perlengkapan dana pensiun. Organ ini berfungsi sebagai alat kelengkapan dana pensiun yang dijabarkan dalam peraturan dana pensiun guna menunaikan manfaat pensiun kepada peserta.

Tindakan organ dana pensiun harus berpijak pada peraturan yang telah ditetapkan pendiri. Sebagaimana yang dijelaskan dalam Pasal 10-13 UU No.11 tahun 1991 tentang Dana Pensiun, juncto Pasal 15-27 PP No. 76 tahun 1992 tentang Dana Pensiun Pemberi Kerja, dan Pasal 9-16 PP No. 77 tahun 1992 tentang Dana Pensiun Lembaga Keuangan, bahwa organ dana pensiun terdiri dari pendiri, dewan pengawas, dan pengurus. Pendiri dana pensiun merupakan organ atau alat perlengkapan dana pensiun yang memegang kekuasaan tertinggi dalam dana pensiun dan padanya diberikan segala kewenangan yang tidak diserahkan kepada dewan pengawas atau pengurus. Pendiri dana pensiun lembaga keuangan bertindak sebagai pengurus dana pensiun dan bertanggungjawab penuh terhadap pengelolaan dan investasi dana pensiun sehingg mampu membayar manfaat pensiun. Sebaliknya, pendiri dana pensiun pemberi kerja tidak ikut dalam mengelola program pensiun, namun berwenang menetapkan peraturan dana pensiun, menunjuk dan memberhentikan pengurus dan dewan pengawas, serta bertanggungjawab penuh atas kecukupan dana untuk memenuhi kewajiban membayar manfaat pensiun kepada peserta.

Dewan pengawas sebagai organ dana pensiun memiliki fungsi pengawasan terhadap pengelolaan dana pensiun yang dilakukan oleh pengurus. Dana pensiun selaku badan hukum (persona standi in judicio) yang merupakan subjek hukum yang mandiri, maka harus diurus oleh pengurus di bawah pengawasan dewan pengawas dana pensiun. Dewan pengawas ini memiliki tugas dan fungsi kurang lebih sama dengan tugas komisaris pada perseroan terbatas. Sehingga, komisaris dari pendiri dana pensiun lembaga keuangan berkedudukan sebagai dewan pengawas dana pensiun lembaga keuangan.
Jurnal Yustika Vol. 23 No. 01, Jul 2020

Halaman $\mid 8$ Analisis Status Badan Hukum Dana Pensiun

Muhhammad Habibi Miftakhul Marwa 
Jurnal Yustika

Vol. 23 No. 01, Jul 2020

Halaman I 9

Analisis Status

Badan Hukum Dana Pensiun

Muhhammad Habibi Miftakhul Marwa
Sedangkan, pengurus dana pensiun sebagai alat perlengkapan eksekutif dana pensiun yang bertugas mengelola jalannya dana pensiun dan memiliki kewenangan mewakili dana pensiun baik di luar maupun di dalam pengadilan. Pengurus dalam mengelola dana pensiun harus mengutamakan kepentingan peserta yang berhak atas manfaat pensiun, dari pada kepentingan pribadi. Pengurus dana pensiun memiliki fungsi dan kedudukan sama seperti direksi pada perseroan terbatas. Pada dana pensiun lembaga keuangan, pendiri dana pensiun lembaga keuangan bertidak sebagai pengurus dana pensiun. Hal ini berbeda dengan dana pensiun pemberi kerja, di mana pendiri tidak terlibat langsung terhadap pengurusan kegiatan dana pensiun.

Idealnya suatu badan hukum yang dibentuk oleh pendirinya, mengakibatkan kedudukan kedua badan tersebut terpisah satu sama lainnya (Wahab, 2001). Namun, berbeda halnya dengan dana pensiun lembaga keuangan di mana kedudukannya masih menyatu dengan struktur organisasi dari badan pendirinya. Hal ini menunjukkan keunikan tersendiri sekaligus menambah khasanah kajian badan hukum di Indonesia, karena terdapat suatu badan hukum di dalam badan hukum. Sehingga badan hukumnya dapat mengikuti bentuk badan hukum pendirinya. Dalam praktiknya penempatan kedudukan dana pensiun lembaga keuangan ini dapat ditempatkan sebagai devisi atau unit kerja lainnya dari badan pendiri sesuai arahan pendiri yaitu bank atau asuransi jiwa. Walaupun kedudukannya menyatu dengan badan pendiri, dana pensiun lembaga keuangan sebagai badan hukum tetap harus mempunyai organisasi, tujuan tertentu, kepentingan, dan kekayaan yang terpisah dengan pendirinya.

Berdasarkan penjelasan di atas, maka dapat dinyatakan bahwa dana pensiun yang benar-benar memenuhi persyaratan sebagai badan hukum yang memiliki alat perlangkapan organisasi dana pensiun yang independen, yaitu adanya pendiri, dewan pengawas, dan pengurus dengan masing-masing tugas dan wewenang yang berdiri sendiri, jelas, dan tidak tumpang tindih satu badan hukum dengan yang lainnya adalah dana pensiun pemberi kerja. Sedangkan, dana pensiun lembaga keuangan tidak memenuhi persyaratan sebagai badan hukum yang independen, karena tugas dan wewenang pendiri, dewan pengawas, dan pengurus terdapat tumpang tindih dengan organisasi bank dan asuransi yang yang mendirikan dana pensiun lembaga keuangan (Wahab, 2005).

Peraturan Dana Pensiun (PDP) merupakan dasar penyelenggaraan dana pensiun, ibarat Anggaran Dasar pada perseroan terbatas yang dimuat dalam akta notaris. Di dalamnya memuat ketentuan-ketentuan yang menjadi dasar kegiatan program pensiun. Pasal 10 UndangUndang Dana Pensiun mengamanatkan kepada Menteri Keuangan (OJK) untuk menetapkan ustu regulasi dan persyaratan badan hukum yang dapat ditunjuk sebagai pengurus. Secara garis besar, sesuai Pasal 4 PP No.76/1992 tentang Dana Pensiun Pemberi Kerja dan Pasal 4 PP No.77/1992 tentang Dana Pensiun Lembaga Keuangan, PDP minimal harus memuat : nama dana pensiun, nama pendiri, karyawan yang berhak menjadi peserta, tanggal pembentukan, maksud dan tujuan pendirian dana pensiun, mekanisme penunjukan dan pergantian beserta tanggungjawab pengurus dan dewan pengawas, sumber kekayaan dana pensiun, syarat peserta, besaran iuran peserta, mekanisme pembayaran manfaat pensiun, tata cara perubahan PDP, dan tata cara pembubaran dan penyelesaian dana pensiun.

Berdasarkan Pasal 6 ayat 2 Undang-Undang Dana Pensiun, dalam jangka waktu 3 (tiga) bulan sejak diterimanya permohonan pengesahan dana pensiun secara lengkap dan benar, maka OJK wajib mengesahkan permohonan pendirian dana pensiun. Segala bentuk penolakan 
pengesahan permohonan, harus disertai alasan penolakan. Dengan demikian, sejak diperolehnya pengesahan dari OJK itulah yang menjadikan dana pensiun sebagai badan hukum dalam arti formil.

Badan hukum dana pensiun yang menyandang subjek hukum telah memenuhi syaratsyarat pendirian badan hukum, karena memiliki harta kekayaan yang terpisah, memiliki tujuan tertentu untuk menyelenggarakan program manfaat pensiun iuran pasti atau program manfaat pensiun manfaat pasti, memiliki kepentingan sendiri untuk mencapai tujuan dana pensiun melalui alat perlengkapan dana pensiun (pengurus), adanya organisasi dana pensiun yang teratur dan rapi yang diatur dalam peraturan dana pensiun, yaitu pendiri, dewan pengawas, dan pengurus, serta memperoleh pengesahan oleh negara.

Harus dipastikan juga bahwa pendiri dana pensiun yang akan menyelenggarakan program pensiun harus didaftarkan sebagai badan hukum. Artinya, setiap penyelenggara dana pensiun yang belum mendaftarkan sebagai badan hukum, maka secara formal penyelenggaran tersebut belum dianggap sah sebagai badan hukum. Akibatnya, semua perbuatan hukum yang dilakukan organ dana pensiun yang belum didaftarkan secara hukum dipandang sebagai perbuatan pribadi bukan perbukan badan hukum dana pensiun.

Dari perspektif hukum dan ekonomi, tidak adanya status badan hukum dana pensiun mengakibatkan dana pensiun kesulitan melindungi aset-aset perusahaan dari pemilik perusahaan sebagai kreditur. Status badan hukum dapat memperkuat posisi tawar dana pensiun ketika berhadapan dengan pihak luar. Kreditur dan pihak luar lainnya dapat dengan mudah berhubungan dengan perusahaan sebagai suatu unit dibandingkan jika mereka berhadapan dengan anggota individu.

Dana pensiun secara teori sebenarnya dapat menggunakan badan hukum Perseroan Terbatas, namun harus diingat bahwa nantinya akan terbentur pada kekayaan dari badan yang mengelola program pensiun tersebut bukan saja berasal dari pemberi kerja, namun dapat berasal dari karyawan yang merupakan peserta dana pensiun. Demikian juga dengan badan hukum koperasi, di mana sesuai dengan Undang-Undang Nomor 25 Tahun 1992 tentang Perkoperasian, koperasi merupakan himpunan modal bukan himpunan modal, didirikan oleh anggota bukan didirikan oleh pemberi kerja. Hal ini mengakibatkan bentuk badan hukum koperasi tidak tepat digunakan untuk wadah program dana pensiun yang didirikan oleh pendiri, yaitu pemberi kerja atau perusahan.

Badan hukum yayasan sebelum ada Undang-Undang Dana Pensiun memang pernah digunakan untuk mengelola program pensiun. Bahkan hampir seluruh program pensiun sebelum disahkannya Undang-Undang Dana Pensiun berbentuk yayasan dana pensiun (Hasibuan, 2011). Namun penggunaan badan hukum yayasan dianggap mempunyai kelemahan, diantaranya yayasan tidak memiliki anggota, sedangkan dana pensiun anggotanya adalah peserta (karyawan) yang ikut iuran setiap bulan. Umumnya yayasan bergerak dalam kegiatan sosial atau non profit, sedangkan dana pensiun orientasinya profit oriented karena hasil keuntungannya digunakan untuk membayar manfaat pensiun kepada peserta. Sehingga yayasan ini tidak tepat dipakai sebagai wadah penyelenggaraan pensiun.

Uraian di atas menegaskan bahwa dana pensiun memiliki status badan hukum yang mandiri, sehingga padanya berkedudukan sebagai penyandang hak dan kewajiban (subjek hukum). Landasan status badan hukum dana pensiun dapat ditemukan dalam Pasal 1, Pasal 3, Pasal 5, Pasal 6, dan Pasal 7 Undang-Undang Dana Pensiun, juncto Pasal 2, Pasal 3, dan Pasal 4 Peraturan Pemerintah (PP) Nomor 76 Tahun 1992 tentang Dana Pensiun Pemberi Kerja, serta
Jurnal Yustika Vol. 23 No. 01, Jul 2020

Halaman $\mid 10$ Analisis Status Badan Hukum Dana Pensiun

Muhhammad Habibi Miftakhul Marwa 
Jurnal Yustika

Vol. 23 No. 01, Jul 2020

Halaman | 11

Analisis Status

Badan Hukum

Dana Pensiun

Muhhammad Habibi

Miftakhul Marwa

Pasal 40 Undang-Undang Dana Pensiun dan Pasal 2 dan Pasal 4 Peraturan Pemerintah (PP) Nomor 77 Tahun 1992 tentang Dana Pensiun Lembaga Keuangan.

\section{Kesimpulan}

Berdasarkan pembahasan di atas, maka dana pensiun sebagai badan hukum dapat disimpulkan sebagai berikut :

1. Keberadaan badan hukum ditentukan oleh hukum yang berlaku suatu negara. Badan hukum sebagai subjek hukum memiliki kewenangan seperti manusia sehingga dapat melakukan perbuatan hukum melalui organ perlengkapannya setelah disahkan oleh otoritas negara. Badan hukum dapat menjalankan perbuatan hukum sebagai pembawa hak dan kewajiban manusia.

2. Dana pensiun sebagai badan hukum mandiri didasarkan pada Undang-Undang Nomor 11 tahun 1992 tentang Dana Pensiun. Dana pensiun tidak menginduk kepada badan hukum lain karena telah memenuhi syarat materiil dan formil. Pendirian dana pensiun sebagai badan hukum berbeda dengan pembentukan badan hukum lainnya yang harus mendapatkan pegesahan dari Menteri Hukum dan HAM. Status badan hukum dana pensiun diperoleh setelah Peraturan Dana Pensiun yang disahkan oleh Otoritas Jasa Keuangan, menggantikan tugas dan wewenang Menteri Keuangan.

\section{Daftar Referensi}

\section{Buku}

Asyhadie, Z. (2018). Hukum Keperdataan Dalam Perspektif Hukum Nasional, KUH Perdata (BW), Hukum Islam, dan Hukum Adat (1st ed.). Rajaawali Pers.

Black, H. C. (1990). Blacks's Law Dictionary. West Publishing.

Fuady, M. (2013). Teori-Teori Besar (Grand Theory) Dalam Hukum (2nd ed.). Prenadamedia Group. Imaniyati, N. S., \& Putra, P. A. A. (2017). Hukum Bisnis Dilengkapi dengan Kaajian Hukum Bisnis Syariah. PT. Refika Aditama.

Irwansyah. (2020). Kajian Ilmu Hukum (A. Yunus (ed.); 1st ed.). Mirra Buana Media.

Khairandy, R. (2008). Perseroan Terbatas: Doktrin, Peraturan Perundang-Undangan, dan Yurisprudensi (Revisi). Kreasi Total Media.

Marzuki, P. M. (2015). Pengantar Ilmu Hukum (8th ed.). Prenadamedia Group.

Murtir, J. (2012). Hukum Administrasi Negara (I (ed.)). Total Media.

Saebani, B. A., Mayaningsih, D., \& Wati, A. (2016). Perbandingan Hukum Perdata. CV. Pustaka Setia.

Subekti. (1980). Pokok-Pokok Hukum Perdata (XV). PT. Intermasa.

Wahab, Z. (2001). Dana Pensiun dan Jaminan Sosial Tenaga Kerja Indonesia. PT. Citra Aditya Bakti.

Wahab, Z. (2005). Segi Hukum Dana Pensiun (I). PT. RajaGrafindo Persada.

Widjaja, G. (2008). Risiko Hukum sebagai Direksi, Komisaris \& Pemilik PT (Pertama). Forum Sahabat.

Jurnal

Hasibuan, R. I. P. (2011). Dana Pensiun dalam Perspektif Hukum Bisnis syariah. Al-'Adalah 
Fakultas Syariah Universitas Islam Negeri Raden Intan Lampung, X(1), 99-108.

Prananingrum, D. H. (2014). Telaah Terhadap Esensi Subjek Hukum: Manusia dan Badan Hukum. Refleksi Hukum: Jurnal Ilmu Hukum Fakultas Hukum Universitas Kristen Satya Wacana, 8(1), 73-92.

\section{Peraturan Perundang-Undangan}

Undang-Undang Nomor 11 Tahun 1992 tentang Dana Pensiun

Peraturan Pemerintah Nomor 76 Tahun 1992 tentang Dana Pensiun Pemberi Kerja

Peraturan Pemerintah Nomor 77 Tahun 1992 tentang Dana Pensiun Lembaga Keuangan

Peraturan Otoritas Jasa Keuangan Nomor 13/POJK.05/2016 tentang Tata Cara Permohonan Pengesahan Pembentukan Dana Pensiun Pemberi Kerja Dan Pengesahan Atas Perubahan Peraturan Dana Pensiun Dari Dana Pensiun Pemberi Kerja

Peraturan Otoritas JasaKeuangn Nomor 14/POJK.05/2016 tentang Pengesahan Pendirian Dana Pensiun Lembaga Keuangan dan Perubahan Peraturan Dana Pensiun dari Dana Pensiun Lembaga Keuangan

\section{Website}

Otoritas Jasa Keuangan. (2019). Statistik Dana Pensiun Periode September 2019. Available online from: https://www.ojk.go.id/id/kanal/iknb/data-dan-statistik/dana-pensiun/Pages/Statistik-Dana-Pensiun-Periode-September-2019.aspx. [Accessed Nov 11, 2019]. 